\title{
Intermédialités
}

Histoire et théorie des arts, des lettres et des techniques

Intermediality

History and Theory of the Arts, Literature and Technologies

\section{Insecurity Cameras: Cinematic Elevators, Infidelity and the Crime of Time}

\section{Alanna Thain}

Numéro 14, automne 2009

bâtir

build

URI : https://id.erudit.org/iderudit/044409ar

DOI : https://doi.org/10.7202/044409ar

Aller au sommaire du numéro

Éditeur(s)

Revue Intermédialités (Presses de l’Université de Montréal)

ISSN

1705-8546 (imprimé)

1920-3136 (numérique)

Découvrir la revue

Citer cet article

Thain, A. (2009). Insecurity Cameras: Cinematic Elevators, Infidelity and the Crime of Time. Intermédialités / Intermediality, (14), 51-66.

https://doi.org/10.7202/044409ar
Résumé de l'article

À l'instar d'icônes du mouvement automatisé, comme le train, l'ascenseur semble présenter une affinité naturelle avec le cinéma dans la mesure où il crée un espace-temps non habituel. Les ascenseurs dévient les activités et les efforts humains, en déployant d'autres formes de mobilité et de rencontres. En tant que médiums temporels, les ascenseurs représentent des zones de durée où se manifeste explicitement un potentiel de changement. Mais, contrairement aux trains, les ascenseurs n'ont jamais fait l'objet d'études cinématographiques approfondies. Cet article se propose de penser l'axe vertical des ascenseurs cinématographiques à partir de la conception " bergsonnienne " de la durée comprise comme " infidélité à soi ». Le célèbre meurtre dans un ascenseur du film Dressed to Kill (1980) de Brian de Palma servira de point d'ancrage afin de mener cette étude sur le rôle de l'ascenseur au cinéma et dans la culture urbaine. 


\title{
Insecurity Cameras: \\ Cinematic Elevators, Infidelity \\ and the Crime of Time
}

\author{
Alanna Thain
}

\begin{abstract}
n his essay "Up and then Down: The Lives of Elevators", Nick Paumgarten writes: "the elevator, underrated and overlooked, is to the city what paper is to reading and gunpowder is to war", an enabling substrate or support, or, we might suggest, a veritable machine for making cities. ${ }^{1}$ Although Jean Gavois traces the history of elevators back to the time of the pyramids, early elevators were largely restricted to freight, for the simple reason that they so often failed, or to the exceptional passenger, as in the case of the elevators at the Coliseum that would simultaneously raise gladiators to the killing floor. ${ }^{2}$ When Elisha Otis, with a showman's flair, unveiled the safety elevator in 1853 with a dramatic slice of the cable, sending the elevator plunging downwards only to halt well before he hit the ground, and the widespread adoption of electricity in the early $20^{\text {th }}$ century, the rise and fall of passenger elevators became part of the vertical rhythm of modern urban life. ${ }^{3}$ Paumgarten explores the urban elevator through the story of Nicolas White, trapped for 41 hours in an elevator in New York and captured in the quadrant of security camera images in a video that immediately went viral when it hit the Web. ${ }^{4}$ White's ordeal plays out in a brutal bi-temporality; the time
\end{abstract}

1. Nick Paumgarten, "Up and then Down: The Lives of Elevators", The New Yorker, New York, vol. 84, nº 10, April 21, 2008, p. 106-115. Here: p. 108.

2. Jean Gavois, Going Up: An Informal History of the Elevator from the Pyramids to the Present, London, Otis Elevator Company, 1983.

3. Alisa Goetz, "Turning Point: Conveyance and the Paris Exposition of 1900", in Alisa Goetz (ed.), Up, Down, Across: Elevators, Escalators and Moving Sidewalks, London, Merrell, 2003, p. 47.

4. This video is available on YouTube: www.youtube.com/watch?v=p_bMhNI_TY8 (last access May 21, 2010). 
lapse images of his body scurrying around the space, flipping restlessly on the floor and repeating the same futile gestures, are at dissonant odds with the sheer, though abstracted, endurance of his ordeal. The horrifying banality of this security footage in its unlivable temporality is an apt illustration of our modern sense of what elevators are and do; the elevator is a zone of city life suspended from the everyday because of the way it makes the substrate of our urban existence - that tenuous but tangible veneer of connection between individual and mass - uncomfortably palpable. Paumgarten notes that "while anthems have been written to jet travel, locomotives, and the lure of the open road, the poetry of vertical transportation is scant"s; the elevator is the zone of the urban inarticulable. The elevator ride, though nowadays a habitual dead zone of experience, can under certain circumstances return us to the intensity of its roots as a spectacular attraction.

Like the train and other icons of automated movement, the elevator holds a natural affinity with cinema. Both are machines for creating non-habitual space and time. Elevators displace human activity and effort, opening up a range of other types of encounters and modes of mobility. In many ways, the elevator is the quintessential modern urban movement, perhaps even more so than a horizontal flânerie. Visit any old major European urban centre, and you'll find that the climb to the top of the cathedral is the vertical epitome of concentrated power and awe. In the mid $19^{\text {th }}$ century, the towers of the Cologne cathedral were completed and, in a final gesture to a more pedestrian urbanity, it stood as the world's tallest building for a brief gasp of time, before the elegant thrust of the Eiffel tower unfolded against the Parisian skyline in 1889, almost doubling the cathedral's height and displacing a laborious climb with the effortless sweep of elevator movement. René Clair's Paris qui dort (1923) beautifully exploits La Tour's verticality as a playful zone of aberrant movement in a world where time is out of joint, one of innumerable films where vertical structures unleash a free play of gravity defying mobility that transgresses social norms. Today, members of the public can't even climb to the top of the tower, but are herded into elevators if they want to ascend beyond the second floor. The ubiquitous verticality of the modern city would be unimaginable were it not for elevators; nevertheless, verticality remains resistant in its obscurity. In Michel de Certeau's "Walking in the City", between the god's eye view from the top of the tower to the blind 
masses below, the machinic articulation of verticality is missing, leaving an experiential gap between mass and individual. ${ }^{6}$

As time based mediums of transportation, elevators are zones of duration where the potential for difference is made manifest, although usually the differential of this movement is actively dampened. An impinging sociability is normally held in check through the distribution of bodies in space according to unspoken norms, but the more such rules are enforced, the more the supporting substrate of their social fabric is shown to be gossamer thin, or is transmuted into a living fabric. Unlike trains, however, elevators have not come in for the same level of critical interest on the part of cinema studies. Whether this neglect is a result of the cinematic elevator's association with the sensationalistic extremes of horror films or sexual encounters, or because the model of durational change of the elevator is less glamorous and more quotidian than a train sweeping across the landscape, or because the elevator seems to mysteriously reinscribe a transitional marker made redundant in cinema by the cuts of editing, the elevator as a cinematic trope deserves a closer look.

This is not to say that elevators, and vertical transportation more generally, have not been the object of fascination, representation, and critical attention. We might think of Fred Jameson's seminal analysis of post-modernism via a description of John Portman's glass elevators in Los Angeles' Bonaventure Hilton. ${ }^{7}$ To actually ride them is to hesitate between the long tracking shot of the ascent and the montage of the vertical cut between hotel interior and LA cityscape, once again allowing Los Angeles to play itself. A small plaque reminds hotel guests that one of the elevators was used in the film True Lies (1994). Portman said that to "pull the elevators out of the wall made them like moving seats in a theatre." A key element for consideration here is how the vertical movement of elevators suggests new ways of thinking about cinematic mobility and how we articulate technology and flesh. This movement is simultaneously deeply banal - one need only think of the connotations of elevator music-and decidedly non-habitual, at least in the sense of what a body can do on its own. While we may have fleeting instances of phenomenological vertical displacement- pliés, jumping,

6. Michel de Certeau, The Practice of Everyday Life, Berkeley, University of California Press, 1988. For a critique of the miss of vertical movement in de Certeau, see Meaghan Morris, "Great Moments in Social Climbing" in Too Soon Too Late: History in Popular Culture, Bloomington, Indiana University Press, 1998, p. 123-157.

7. Fredric Jameson, Postmodernism, or, The Cultural Logic of Late Capitalism, Durham, Duke University Press, 1991.

8. Phil Patton, "Hovering Vision" in Goetz (ed.), 2003, p. 105-124. Here: p. 111. 
or hanging - a pure and extensive verticality is not part of our habitual register of bodily movement. Despite the fact that verticality characterizes many modern cities, vertical movement remains marginal to our accounts of modern life.

In cinematic representations of the city, there is a missing link between the privileged perspective from the top of a tall building and the flanerie of street level movement. The potential for re-animating bodies that such vertical movement entails emerges then in the gap between the absolutely repeatable and the thrillingly unique, and it is for this reason that elevators in cinema frequently become sites of sensational duration that speak of the cinematic body itself. The vertically oriented scene framed by the elevator is an ergonomics of a potentially mobilized gaze - we are invited to step into a scene that is cut to the measure of our mobility far more so than the standard horizontality of most screens, perhaps more so than the standard horizontality of the cinematic screen.

However, the inviting accessibility of this framed scene to human form is also deeply unsettling in the way it encourages movement between worlds, an incitement to impossible action, highlighting the liminality and unlivability of elevator space itself. This unlivability was made apparent in Paumgarten's account of White's confinement, whose every escape plan came from the movies.

Elevators beg the question of the "what next" of movement, and at the same time can make this deeply disturbing via the structural possibilities of the irrational cut, the sense that the regularized predictability of elevator delivery services might not deliver you where you intend to go, as in horror films such as Honogurai mizu no soko kara (Dark Water, 2002) from Hideo Nakata or The Thirteenth Floor (1999) from Josef Rusnak, or the mediated and magical subjectivity of Being John Malkovich (1999) from Spike Jonze. Murray Pomerance identifies this potential for irrational displacement as a characteristic of "elevator films", like David Cronenberg's eXistenZ (1999), albeit in films which do not explicitly feature elevators. ${ }^{9}$ Such unlivability is also likely the source of the elevator's starring role in narratives of infidelity, from The Apartment's (1960) in wich Shirley McLaine works as an elevator attendant through the public privacy of the cage elevator as the site of steamy sexual encounters in films like Fatal Attraction (1987). Like the motel room as the space of American infidelity in Foucault's account of heterotopias, the elevator is both the site of spectacular encounters holding up a mirror to social

9. Murray Pomerance, "Neither Here Nor There: eXistenZ as "Elevator Film", Quarterly Review of Film and Video, vol. 20, $n^{\circ}$ 1, January 2003, p. 1-14. 
norms and a space cut off from and obscure to everyday life. ${ }^{10}$ In its displacement of the two hotel rooms in Hitchcock's Psycho (1960) (Marion Crane's sexual encounter in Phoenix bookended by her sexualized murder in the Bates Motel) by the elevator as the condensation of sex and death, Brian de Palma's Dressed to Kill (1980) elevators in cinema are transitional zones for becoming other than what you have been. In what follows, I will explore "elevator time" as duration made sensible through the spectacular criminality of sex and death in cinema, particularly through a reading of the elevator murder in De Palma's Dressed to Kill. Peter Hall, in "Designing Non-Space: The Evolution of the Elevator Interior", describes how "the silenced, enclosed cab has the effect of exaggerating every rider noise, move and gesture. The potential for erotic liaisons with friends or strangers in elevator cars, coupled with the possible thrill of sudden exhibitionism, has become a movie trope in itself as a result of these peculiar acoustic and social conditions." ${ }^{\prime \prime}$ He illustrates this with an ad for Captivate (an elevator safety company) that captures how the dangerous thrill of an illicit sexual encounter displaces the fear of elevator malfunction; this print ad shows a semi-clad couple locked in an embrace in an elevator, while the text proclaims "what you do inside is your business - getting you in safely is our business." However, even beyond the acoustic and social conditions of the elevator space itself, the fear of death serves as a foundational "amplifier" in the elevator's affective force.

The lack of a richly developed language for assessing vertical movement in cinema studies at least in part has to do with the way in which a pure verticality is largely inaccessible to humans, except in the movement towards death, i.e., falling. ${ }^{12}$ Falling retains a metaphoric charm (falling in love) but when actualized is deadly to the body. That sense of love's vertiginous fall may be one of the reasons why cinematic elevators have a particular suitability as staging grounds for scenes of infidelity, and relatedly, spectacular sex and violence. In fact, fear of falling is something that elevator designers negotiate in their work all the time,

10. Michel Foucault, "Of Other Spaces", Diacritics, vol. 16, n 1, Spring 1986, p. 22-27.

11. Peter Hall, "Designing Non-Space: The Evolution of the Elevator Interior" in Goetz (ed.), 2003, p. 59-78. Here, p. 71.

12. Some recent explorations of verticality in cinema include David Bordwell's "Paolo Gioli’s Vertical Cinema", David Bordwell's Website on Cinema, August 2009, www.davidbordwell.net/essays/gioli.php (last access May 22, 2010), on the work of this experimental filmmaker to reemphasize the vertical movement of the film image through the machine (editing and projection), and Kristen Whissel's "Tales of Upward Mobility: The New Verticality and Digital Special Effects", Film Quarterly, vol. 59, n 4, Summer 2006, p. 23-34. 
and one of the mechanisms for dealing with this is an emphasis on what Henri Bergson would call spatialized time ${ }^{13}$ : in the numbers that light up for each floor as a stand-in for the reassuring regularity of clock-time, or in "smart" elevators, a light that indicates which elevator will be yours where goes on well before the elevator arrives, translating an unruly "when" into a calming "here", managing what elevator designers call "psychological waiting time". ${ }^{14}$ As Hall describes the reason behind such management: "The history of elevator design might be summarized as a series of schizophrenic attempts alternately to celebrate and disguise the awe and terror of vertical ascent, the miracle of levitation".15

Why is time management so critical to the smooth execution of elevator movement, and how might it suggest the radical potential of another kind of time that animates elevator mobility? In 1998, an Israeli engineer named Ori Yardeni began building what he would dub "Time Elevators", multimedia cinematic experiences in which spectators seated on motion base platforms "journey through" the strata of history, each floor a different era with an appropriate simulation of movement and effects. Here, vertical movement is subordinated to temporality as privileged segments of time, the selected slices supplemented by excessive sensory titillation. Yardeni's time elevators as rides call attention to a qualitative experience of sensation but regulate this in relation to external spectacle - time itself is tamed as history and put to the service of bodily pleasure. I want to explore an opposite sense of the elevator as cinematic time machine, one interested in duration itself as a sensational form of qualitative change, an experience explicitly dampened in our everyday experiences, but also in the spectacular non-everydayness of Yardeni's rides. Elevators routinely disguise the qualitative experience of riding in them: from the lighting up of floor numbers not only as spatial coordinates but also as a way of translating duration in quantitative terms, we are distracted from the passage in-between, in part as a way of controlling the sensations of fear at the potential of bodily destruction via falling. As Paumgarten writes:

Otis has conducted research to find out whether people might better enjoy their time in elevators if it were more of an experience - if it would somehow help to emphasize that they're in an elevator, hurtling up and down a shaft. Otis found, to little surprise, that people would rather be distracted from that fact. Even elevator music, designed

13. For his discussion of spatialized time, see Henri Bergson, Time and Free Will: An Essay on the Immediate Data of Consciousness, New York, Cosimo, 2008.

14. Paumgarten, 2008. p. 110.

15. Hall, 2003, p. 71. 
to put passengers at ease, is now so closely associated with elevators that it is no longer widely used. ${ }^{16}$

Cinematic elevators have the advantage of exploiting gaps in our habits, allowing something else to emerge. In line with this, and my rather unscientific survey, cinematic elevators frequently appear at critical moments to make something happen, and my main example here will be the elevator murder scene from Dressed to Kill. Against our quotidian indifference to the real movement of elevator displacement itself, in De Palma's film duration is made apparent in an outburst of spectacular violence closely linked to sexual encounter. The vertical movement of the elevator as scene of the crime haunts the film and foregrounds the problem of fantasy duration and spatialized time.

The work of the cinematic elevator finds an echo in Anne Friedberg's theory of the mobilized and virtualized gaze, born out of the convergence in the $19^{\text {th }}$ century of "machines of mobility", including elevators that produced a "mobilized visuality" and devices of virtual visuality, such as the cinema. ${ }^{17}$ In particular, the tension between the immobile spectator and the mobilized scene can lend itself to aberrant experiences of time and movement; I would argue then that elevators are a kind of intermediate movement, a suspended-in-between, with the spectator caught, as it were, in the blink of the projector's eye. Friedberg claims that one of the major results of this mobilized virtual gaze is a new temporality, a "detemporalized subjectivity" at odds with the regular experiences of structured rationalized time of modernity. ${ }^{18}$ Cinema is, in effect, a machine for virtual time travel, in three ways: first, as a theatrical set-piece, set in the past or future; second, in its capacity through montage to elicit an elliptical temporality, and third, in its ability to be repeated over time, imparting to each viewer a montage consciousness. Thinking about cinema in these terms, she claims, challenges the "perspective paradigm" and subject-centered film analysis. We might, however, add another element, which is key to the way that Gilles Deleuze characterizes the shift from the movement-image to the time-image in his cinema books, and which retains the disruptive force of generating new images of

16. Paumgarten, 2008, p. 110.

17. Anne Friedberg, Window Shopping: Cinema and the Postmodern, Berkeley and Los Angeles, University of California Press, 1994 and The Virtual Window: From Alberti to Microsoft, Cambridge (Mass.), MIT Press, 2006.

18. Friedberg, 1994, p. 2. 
thought: cinema's ability to induce an intensive consciousness of duration. ${ }^{19}$ As in Friedberg's work, the effect of this is also to displace our thinking of cinema in terms of the subject, to open up an into cinematic modes of subjectivation. In considering elevator temporality in Dressed to Kill, I focus on the way that this elevator sequence negotiates subjective and objective times, as an example of such an inquiry. In Cinema 1, Deleuze makes the following proposition:

A subjective perception is one in which the images vary in relation to a central and privileged image; an objective perception is one where, as in things, all images vary in relation to one another, on all their facets and in all their parts. These definitions affirm not only the difference between two poles of perception, but also the possibility of passing from the subjective to the objective pole. For the more the privileged center is itself put into movement, the more it will tend toward an acentered system where the images vary in relation to one another and tend to become like the reciprocal actions and vibrations of a pure matter. What can be more subjective than a delirium, a dream, a hallucination? But what can be closer to a materiality made up of luminous wave and molecular interaction ${ }^{20}$

This fine line between hallucination or dream and the movement of matter itself, the dispersive sensation of a multitude of durations, is a key to the importance of the elevator's contagious subjectivations. In Louis Malle's Ascenseur pour l'échafaud (Elevator to the Gallows, 1958), one man's immobilization in a stuck elevator sparks a long detour of his identity and murderous intent, stolen along with his re-mobilized car and circulated throughout the city via the media. The redoubling of automated movement can, in certain films, make apparent that "becoming in time" that is the infidelity of the self to a single, subjective point of view.

\section{ELEVATORS AND THE NON-PLACES OF INFIDELITY}

In the final scene of Yvan Attal's Ils se marièrent et eurent beaucoup d'enfants (Happily Ever After, 2004), in which Charlotte Gainsbourg struggles to accept her husband's infidelity and its implications for their marriage, we see real estate agent Gainsbourg meeting a handsome new client (Johnny Depp, in an uncredited cameo) for an elevator ride to an apartment. As they ascend, this banal

19. Gilles Deleuze, Cinema 1: The Movement-Image, trans. Hugh Tomlinson and Barbara Habberjam, Minneapolis, University of Minnesota Press, 1986 and Cinema 2: The Time-Image, trans. Hugh Tomlinson and Robert Galeta, Minneapolis, University of Minnesota Press, 1989.

20. Deleuze, 1986, p. 76-77. 
displacement, filled initially with small talk, is stretched beyond all possible reason as their trip seems to go on interminably, languorously cutting between Gainsbourg and Depp as the elevator eventually, inexplicably, rises through the building into the sky above as they begin to kiss. A bare rhythm to keep time is transformed into a romantic piece of music as the film ends ambiguously on the question of whether or not Gainsbourg's character will take a lover - a quotidian infidelity that shatters the fixed image of the fairy tale future of the title. Is this a subjective fantasy on her part? On Depp's? Or is subjective the wrong word for the potential of this scene? The scene is infused with ambiguity; she has seen Depp before in a record store where they have a brief flirtation, but it is unclear if she recognizes him, or vice versa; when the scene makes the shift from a perversion of destination via an extended temporal sequence highlighted by lots of cuts that stretch time into an ultimately fantasmatic setting, we can't be sure if this is happening or not, or better yet, we're not sure how this is happening. Depp's tempered anonymity in this scene speaks to the way that elevators make felt the social fabric of urbanity by making a substrate of relationality itself apparent; the potential of connection is actively sensed, rather than assumed, in such spaces. As Elizabeth Grosz describes this: "the city's form and structure provide the context in which social rules are internalized or habituated in order to ensure social conformity or position social marginality at a safe or insulated distance or boundary;" elevators are an exaggerated micro-ecology of such rules, intensified to an unbearable tension in cinematic elevator encounters. ${ }^{21}$

Sparked by the narrative potential for infidelity, movement becomes aberrant here. Deleuze claims that "what aberrant movement reveals is time as everything, prior to the controlled flow of any action." 22 In making this claim, Deleuze is challenging the propensity to think the cinematic image as "in the present." The dead time of elevator movement is a good example of such an idealized "present time" that is agonizing to confront because it is often felt as depotentialized duration, but can also open onto a more complicated present. The felt virtualities of past and future impinging on this scene in Attall's film suspend this present moment. The ambiguities of the subjective (fantasy, memory, etc.) infected by the elevator movement as machine for sensing duration might make us read this scene as a displacement in space-time rather than a simple physical movement

21. Elizabeth Grosz, "Bodies-Cities", in Janet Price and Margrit Shildrick (eds.), Feminist Theory and the Body: A Reader, New York, Routledge, 1999, p. 381-387. Here, p. 386.

22. Deleuze, 1989, P. 37. 
in space. In terms of the subject, we might describe the effect of sensational duration as felt becoming - an infidelity to a fixed sense of the self.

Brian de Palma's thriller Dressed to Kill remixes Hitchcock's Psycho and plays off of that film's notorious disciplining of cinematic time, with Hitchcock's insistence that, contrary to common practice, no viewers would be admitted to the cinema after the film had started in order to preserve the shock of Janet Leigh's death. De Palma sprinkles elements of Psycho throughout Dressed to Kill, and the elevator murder reimagines the notorious shower scene. Both the motel room and the elevator are liminal spaces turned dead ends for main characters, forcing both films into a disorienting refocalization. De Palma condenses Hitchcock's longer demurral of Janet Leigh's punishment for her sexual transgression in a hotel room high atop Phoenix, her financial transgression and subsequent flight across the long horizontality of the American highway, into the vertical loop of an elevator ride down and back again from a lover's apartment. The elevator becomes a setting for an aberrant experience of time a witnessing and exchange of perspectives. If, as Friedberg argues, the virtual mobilized gaze has as one of its key effects new modes of temporality, I want to use this to think about durational elevator time and the insecurity camera in Dressed to Kill as a witnessing gaze.

The first part of the film follows Kate Miller, a bored and sexually frustrated housewife, through her day. The opening scenes alternate between two temporal modes: subjective time as heightened experiences of fantasy in which durational time is foregrounded through slow motion, repetition, a delinkage of sound, image, visual excess, and the more familiar constructed "everyday time" of narrative cinema, in which, however, rationalized and spatialized time is a constant theme. For instance, the film opens with a slow motion shower sequence, quickly revealed to be Kate's fantasy, where she masturbates in front of her oblivious husband before being attacked by a stranger. The very next scene is her routine morning sexual encounter with her husband, choreographed to the soundtrack of the morning radio traffic report, with its regular updates of incremental time changes ("it's now 7:42 am", etc.) which allow people to maximize their morning efficiency and be propelled off to work. Kate's husband literally works to this deeply habitual beat in her "slam bang session".

At her psychiatrist's appointment, she asks him not to keep her waiting, as she has to meet her mother in law at 12:30 but wants to go to the museum first, stealing a bit of time for herself between her scheduled encounters. Moving from the domestic sphere of the home and the presumed privacy of her therapy sessions to the city involves a series of negotiations that expose the immersive 
relationality of urban space itself, the erotic dangers of public intimacy. The first part of the film offers a triptych of settings of intensified anonymity and mechanical mobility: the famous sequence at the art museum in which virtuoso camerawork and a sound image disjunction charge the public space of the museum with the intimacy of flirtation and pursuit; the taxi ride as a scene of public sex and display; and the murder in the elevator ambiguously positioning the modern high rise between the private space of home and the anonymous space of the hotel room. At the museum, Kate alternates between indulgent contemplation and banal obligations - making a grocery list in front of the paintings, including the infamous note to "pick up turkey" as a handsome stranger sits down beside her. The museum sequence is justifiably famous, as the pursuit/reverse pursuit scene in which Kate first chases the stranger and then flees him, is shot in long following tracking shots to a deeply artificial soundtrack where ambient noise falls away and we only have the ironic metronome of Kate's clattering high heels, their irregular beat pulling against the sense of real time of the long take. The anticipatory urgency of this scene marks the intrusion of fantasy time into this live scene. Kate flees the museum, only to spot the stranger who invites her into a taxi where he goes down on her in a scene that mixes Kate's self-pleasuring fantasy with her "real life" vocalizations of pleasure. Her orgasmic cry is coincident with a vertical tracking shot that reappears at several key points in the film, and which insistently links death, sex, danger and transport. When they arrive at the stranger's apartment, another vertical track up the side of the building functions as an external elevator movement and also transitions from day into night through a cross fade, again emphasizing the sense that the vertical movement of elevator time runs contrary to naturalized measures of time and transition. We then return to a kind of insistently "real" time, as Kate awakens to look at her watch on top of his clock and realizes she has to leave. Fantasy time persists, though, through the use of long single-take tracking shots, until she finds a letter stating that her new love has a venereal disease, shattering her fantasy of privacy via the impersonal publicity of the sexual citizen. Kate flees into the hallway; upset and distracted she fails to notice the shadowy figure (Dr. Elliot, present in drag as his feminine alter ego Bobbie) peering at her from the stairwell. She gets into the elevator just in the nick of time, as a tracking shot from the doorway to the elevator suggests that the stranger is trying to reach her. It's worth noting that at this point, Kate has the chance to escape if she just doesn't double back to fetch her ring, that symbol of homogenous and standardized duration. 
The first part of the film has several split screen memory flashbacks in which Kate remembers losing bits of her clothing - her glove in the museum, her underwear in the taxi, and now, in the elevator, her forgotten wedding ring (that symbol of homogenous future time) abandoned on top of the clock in the apartment upstairs. Typically for the mixed time experiences of this film, the memory image is simultaneously narratively functional by motivating her return (as Deleuze would say, this is not really a disruptive direct image of time but an indirect representation), and formally showy, a clunky way to show an image of thought. As soon as she remembers, she frantically pushes the button for the seventh floor but to no avail, as she's already going down. A mom and child step into the elevator, the child repeatedly staring at Kate in a clear breach of elevator etiquette, subjecting her to the unblinking duration that makes Kate, framed in a close up that, due to the black wall behind her, makes her appear to be no place, deeply uncomfortable. This five minute long elevator sequence that repeatedly highlights the glowing numbers and their relentless pacing is at odds with Kate's bodily agitation and sense of urgency. Again, the scene unfolds in two distinct temporal registers - one bodily and affective and the other mechanical and regular; in the gap between, we have elevator time. Once the other passengers step out, Kate repeatedly presses the $7^{\text {th }}$ floor button. An engineer for Otis elevators notes in Paumgarten's article that people report feeling like they can control elevators through such actions but that in fact it makes no difference, and Kate's agency is continually re-regulated throughout this scene. As she rises we alternate between close ups of Kate's face and close ups of the numbers, the cross cutting generating a bodily suspense out of proportion to the regulated movement; these two registers contrast during the actual murder scene.

The elevator in this sequence is an unexpected scene of such violence, as it is literally a bare cube with almost nowhere to hide, though the editing and framing in the scene make the space ambiguous and full of such deceptive potential. Certainly that sense of public privacy on display is evident in the scene of Kate's perusal by the child, where only social convention serves to shield Kate: "It's not polite to stare", the mother says. The witnessing gaze, however, is also built into the cross cutting during Kate's descent with a man and a woman waiting for the elevator below. Both are dressed in career clothing, and they are discussing hot stock tips. It doesn't become evident until later that this woman is Liz, a high class escort who remains ambiguously positioned between sex worker and savvy businesswoman throughout, and this identity oscillation, initiated while waiting for the elevator, returns in the famous "Donahue" cross-cutting and split screen sequence later in the film. The elevator movement itself, though, can serve as a 
stand-in for such formalist attempts to represent complex time and simultaneity precisely because of its ability to make one feel duration.

The scene of Kate's murder, graphically violent and gruesome, and contrasted with the blasé endurance of Liz and her client below, brings together the two affective registers of elevator movement: bodily terror and passive banality. At the end of the elevator scene, the evidentiary force of vision is compromised through a manipulation of standardized time - the use of slow motion to extend the scene - and the play on distorted vision. As the elevator door opens in front of Liz, the scene shifts into slow motion as she tries to register what is happening in front of her, seeing Kate's bloody body slumped in the corner, but not seeing the killer Bobbie, who hides just out of sight. As Liz struggles to focus, Kate reaches for her just as the killer starts to slash at Liz's extended hand. The glare from Kate's watch and the glint of the knife momentarily blinds Liz, but this disjunctive synthesis of clock time and action produces another vision, a reoriented gaze as she looks away into the security mirror and sees what's happening inside; Liz becomes a human insecurity camera - registering without being able to act or intervene. What is interesting in this scene is the strange and oneiric feel of it, created by aberrant movement - both the stretched out time, but also the strange juxtaposition between the cinematic time of slow motion and the curiously static nature of the figures in the scene. Characters are frequently posed and the camera instead moves for them, highlighting what Friedberg calls the "mobilized virtual gaze" and opening another power of vision that is non-functional. No one is saved or even revealed per se; we have only a kind of contagious witnessing as the doors close on Liz's anxious face and she can only snatch up the dropped razor. Mistakenly taken for the killer by a frightened neighbour, she will instead become the hunted, the unwitting bait for the cops, and a detective in her own right. The stasis of this scene is crucial to conveying a sense of real durational movement, and not simply the movement of subjects - to speak to the enduring verticality of the elevator. As Constantin Boundas puts it: "it is consciousness which constitutes the opaque blade without which light would go on forever"; in this scene, that blunt opacity extends into the drawn out glare that opens another vision, but also in the pre-reflective recording without registering what Liz undergoes. ${ }^{23}$ Kate, condemned by her desire to return for her ring (which she never reaches), doesn't succeed in escaping her stance as bored housewife, but Liz is in

23. Constantin V. Boundas, "Deleuze-Bergson: An Ontology of the Virtual" in Paul Patton (ed.), Deleuze: A Critical Reader, New York, Wiley-Blackwell, 1996, p. 81-106. Here, p. 84 . 
the lived process of becoming other to herself. The ambiguous ethics of responsibility that embroils Liz as a result of this chance encounter undoes the everyday anonymity of the elevator and makes it a zone of encounter, reminding us that the intensive sensation of duration, for Deleuze and Bergson, necessarily opens us to the felt awareness of other experiences, subjectivities and the play of matter itself. This is the real infidelity of the scene, the "crime of time", to cite Deleuze, playing out in the suspended zone of the cinematic elevator. ${ }^{24}$

The witnessing gaze, made possible by elevator time, becomes crucial for the unfolding of the rest of the film, in which rationalized vision and clock time are inadequate to the expression of the horror experienced. Kate's son attempts to solve the mystery of his mother's murder by building an elaborate automated stop motion film camera to record the comings and goings of Dr. Elliot's visitors. We see the building of the camera, but this fails as a tool of vision as it cannot capture Elliot's double self, the miss of recognition suspended in the black between the frames. Elevator criminality in Dressed to Kill is all about the crisis of time, when time is "out of joint" and we are made to feel it through the body. This witnessing is not only about a memory to be activated but something else entirely - not just a "what did you see", but also the failure of a sampled record or indirect image of time in favour of a Bergsonian pure past. As Bergson describes this: "we perceive virtually many more things than we perceive materially and actually."25

Dressed to Kill is ostensibly about the murder by a split subject, Dr. Elliott/ Bobbie, whose psychic split continually infects the film's formal structures. The film's elevator criminality suggests, however, that "the only crime is time", in that it is in time that the self becomes split in becoming double (that is to say in Deleuzian terms, experiencing the splitting of the present into the present that passes and the past that is preserved) and experiences duration, the becoming of difference. In Dressed to Kill, the violent murder scene has often been read as anti-feminist moralizing, a vengeful just deserts that delights in the sadistic murder of Kate. To think about that scene in terms of the cinematic elevator, however, is to read it as something else, not just narrative suspense, but a suspension of durational potential - a potential for becoming other, for "ventilating our static materialities and temporalities", as Friedberg puts it. ${ }^{26}$ This potential

24. Deleuze, 1989, p. 37.

25. Henri Bergson, "Letter to G. Lechalas", in Keith Ansell Pearson and John Mullarkey (ed.), Henri Bergson: Key Writings, New York and London, Continuum, 2002, p. 354356 . Here, p. 355.

26. Friedberg, 1994, p. 4. 
of elevator time is subdued in the film by the pull of the narrative mystery, the answer to which hides in plain sight, but reemerges at the end of the film in three critical scenes. Except for the Donahue scene, where cross cutting and a split screen are used to draw ambiguous parallels between Kate and Dr. Elliot through the shared echo of a Phil Donahue show on transvestites, after the elevator murder we lose the elaborate sense of uncertainty around fantasy of the opening section where Kate's "subjective" presence infuses and makes uncertain action. The formal showiness of the Donahue sequence is moderated by the "explanatory" nature of the time machines in the scene - the telephones and the television sets, which modulate the temporal and spatial disjunctions of these apparatuses through their familiarity and a kind of subjective origami of these complicated folds of identity of both Liz and Dr. Elliott. But the polar opposition of subjective and objective perception regains a productive indistinction at the end of the film via two key scenes that reanimate the duality of elevator time as the importance of the intensive in-between, and remind us to ask where the reductive clarity of the bird's eye view comes from. In the first, Liz and Kate's son hash out the details of transsexualism over a "postmortem" lunch atop a skyscraper, after Dr. Elliott has been arrested and unmasked as both murderer and cross-dresser. There is no sense of how they got there; they float above the city and are untouchable. Despite repeated shocked looks from a "lady who lunches" at a nearby table at Liz's frank talk, they are immune to such social pettiness and secure in their camaraderie. Given the importance of vertical movement in the film, the cut to the rooftop perspective both signals their safety and the clarity of insight that the psychological analysis of Dr. Elliott seems to promise. The final effect of verticality, however, renders such clarity suspect and returns Liz to a world where the subjective and the objective are not affectively distinguishable. This second instance is during the following scene, set in a fantasy Bellevue, dark, gothic and swarming with danger, sliced through by a lithe nurse in a tight uniform, who is attacked, murdered and undressed by Elliot. The final shot tracks upwards from the body, framing the leering crowd. A scene of Liz in the shower at Kate's follows this vertical track, again in slow motion, bookending the film. Again, the glint of the razor blade suggests a different type of vision, and bodily displacement serves to inaugurate horror. The murderer gets the jump on her via an illusion of spatial immobility: Liz spies a pair of shoes peaking around the edge of the bathroom door, only realizing they are an empty lure at the moment that the unshod killer sneaks up behind her to slash her throat. Bodily displacement and aberrant movement are the mediums of horror here. When Liz awakes, screaming, we see the displacement of vertical automated movement, the 
threat of falling. The virtual here is caught in the indistinct exchange between dream and waking life.

In the encounter between two technologies of movement, elevator criminality in Dressed to Kill uses the dramatic violence of the elevator murder to highlight the unstable becomings of the "crime of time", the sensed duration of the self's infidelity to the subject. Elevators are condensations of encounters, at once a space in which social convention is all the more rigorously reworked in its heightened apperception, and zones of the movement of the virtual itself. Abbas Kiarostami once asked all the participants in his filmmaking workshop at the London Film School to set all of their films inside an elevator, since it was a "magic box for stories". ${ }^{27}$ Certainly some of that magic potential comes from the intensification of social encounter that the automated verticality of the elevator brings to the urban experience. In Murray Pomerance's "elevator films", characters use a technological interface to "skip instantly [...] into a second reality", where the immediate and banal movement into an "other world" evaporates spatial and temporal coordinates and with them, a class-consciousness marked by the body in the here and now. ${ }^{28}$ Here, however, I want to argue for a reanimated potential for the elevator in films that take seriously the question of its duration and that use a new visibility of an old, though still ubiquitous technology, to reimagine film form. Vera Chitylova’s Sedmikrásky (Daisies, 1967) is one example in that the film's explicit foregrounding of the cut-up and collage as textual technique reanimates the temporality of the cinematic edit during the sequence where the girls ride a dumbwaiter up to the climactic banquet scene, and where with each opening, the banality of a new scene at each floor reawakens us to the strangeness and mystery of cinematic assemblage. The enduring verticality of the cinematic elevator can likewise reanimate for cinema studies a sense of the cinematic time machine's potential to create non-habitual spaces and times out of the most everyday banality.

27. Paul Cronin, "Four Golden Rules", in The Guardian, June 17, 2005. See www.guardian.co.uk/film/2005/jun/17/1 (last access May 22, 2010).

28. Pomerance, 2003, p. 1. 